University of Rhode Island

DigitalCommons@URI

2018

\title{
The Individual Determinants of Support for Open Space Bond Referendums
}

\author{
Patrick Prendergast \\ University of Rhode Island \\ Shanna Pearson-Merkowitz \\ University of Rhode Island, shanna_pearson@uri.edu \\ Corey Lang \\ University of Rhode Island, clang@uri.edu
}

Follow this and additional works at: https://digitalcommons.uri.edu/psc_facpubs

The University of Rhode Island Faculty have made this article openly available.

Please let us know how Open Access to this research benefits you.

This is a pre-publication author manuscript of the final, published article.

Terms of Use

This article is made available under the terms and conditions applicable towards Open Access

Policy Articles, as set forth in our Terms of Use.

\section{Citation/Publisher Attribution}

Prendergast, P., Pearson-Merkowitz, S., \& Lang, C. (2019). The individual determinants of support for open space bond referendums. Land Use Policy, 82, 258-268. doi: 10.1016/j.landusepol.2018.12.009

Available at: https://doi.org/10.1016/j.landusepol.2018.12.009 


\title{
The Individual Determinants of Support for Open Space Bond Referendums*
}

\author{
Patrick Prendergast \\ $\mathrm{PhD}$ Candidate, University of Rhode Island \\ Shanna Pearson-Merkowitz \\ Associate Professor, University of Rhode Island \\ Corey Lang \\ Associate Professor, University of Rhode Island
}

\begin{abstract}
The ubiquitous use of ballot referendums in the public finance of land conservation means that conservation policy is often made at the individual voter level. However, studies to date have relied on either aggregate vote outcomes or surveys of residents of small geographic areas facing high growth. In this article, we utilize an original national survey to investigate a series of questions that pertain to individual opinion on open space preservation with a special focus on respondents' perception of open space in their community. We find that most demographic variables that are determinants of open space and land use preferences in studies that use aggregate data and cover a limited geographic range are not statistically significant in our models. We also find that perceptions about the amount of open space available in ones' community, not objective open space measurements, are a statistically significant and robust determinant of open space bond support. Our results indicate that policy advocates may be able to increase the probability of support for public financing of open space preservation by focusing on people's perceptions of the scarcity and disappearance of open space.
\end{abstract}

\footnotetext{
* This work was supported by the USDA National Institute of Food and Agriculture, Agricultural and Food Research Initiative Competitive Program, Agriculture Economics and Rural Communities, grant number: 2015-67024-22937.
} 


\section{INTRODUCTION}

Land conservation is a popular tool to preserve natural resources and curb growing development in the United States. By the end of 2015, state, local, and national land trusts had conserved 56 million total acres of land and managed $\$ 2.18$ billion in endowments and dedicated funding (Land Trust Alliance 2015). This type of policy activity suggests widespread support for government policies that devote resources to land conservation, but the literature to date is limited regarding what influences individual preferences for these types of policies. The availability of land conservation referendum voting data is a convenient way to analyze such preferences (e.g. Kotchen and Powers 2006; Kline 2006; Nelson, Uwasu, and Polaski 2007; Schmidt and Paulsen 2009; Banzhaf, Oates, and Sanchirico 2010; Altonji et al. 2016; Lowry and Krummenacher 2017; Lowry 2018), but the use of aggregated data does not allow for an accurate assessment of the extent to which individual perceptions of land use change influences support for land conservation policies and expenditures.

The ubiquitous use of ballot referenda in the public finance of land conservation means that conservation policy is often made at the individual voter level and a better understanding of the individual determinants of vote support would be valuable to policy-makers and advocates. To this end, here we utilize an original national survey to investigate a series of questions that pertain to individual opinion on open space preservation with a special focus on respondents' perception of open space in their community. Building off the literature to date, we ask: How well do actual open space amounts align with people's perception of their community's available open space? What role does perception of open space play in preferences for publicly funded environmental projects? And finally, which is more strongly correlated with respondent's support for open space preservation: objective or subjective assessments of land use change? 
First, we test whether objectively measured open space in respondents' communities influence individual level bond support. Results indicate that objectively measured open space is not a statistically significant determinant of bond support at the individual level. Second, we test the role of respondents' subjective perceptions of community open space on their support for open space bonds. We find that perception of community open space is a statistically significant and robust correlate of open space bond support: respondents that perceive a small [large] amount of open space in their community are more [less] likely to support an open space bond, regardless of the actual amount of open space there is in their community. Our findings add to the literature by investigating individual preferences for open space bonds in a generalizable, national survey setting while using a novel explanatory variable to explore individual conservation preferences.

The comparison of objective and subjective environmental measurements has been investigated in valuation studies related to water quality (Poor et al. 2001; Artell, Ahtiainen, and Pouta 2013), pollution (Minguez, Montero, and Fernandez-Aviles 2012), natural space attractiveness (Daams, Sijtsma, and van der Vlist 2016), and traffic noise (Baranzini, Schaerer, and Thalmann 2010), as well as others. Past studies have also examined whether perception of land change influences landowners' willingness to grant conservation easements (e.g. Brenner et al. 2013). To our knowledge, we are the first to study the relationship between perceptions of community open space and objective measurements of open space. Our elicitation of voter perception of open space is an advantage over previous literature because we do not have to assume perception is constant within geographies.

\section{SUPPORT FOR LAND PRESERVTION BALLOT MEASURES}


Ballot referenda have been a popular source of data to analyze preferences for environmental issues because voting in elections is considered a good measure of revealed preferences for environmental goods. ${ }^{1}$ Many studies rely on aggregate demographic data to understand the drivers of land conservation policy adoption (e.g. Deacon and Shapiro 1975, Kahn and Matsusaka 1997, Romero and Liserio 2002, O'Connell 2008, Allen et al. 2013). This practice has extended to studies that use aggregate data to explain how land use characteristics of the locations that hold environmental referenda affect voting success (Kline and Wichelns 1994; Howell-Moroney 2004; Solecki, Mason, and Martin 2004; Kline 2005; Kotchen and Powers 2006; Nelson, Uwasu, and Ploasky 2007; Schmidt and Paulsen 2009; Banzhaf, Oates, and Sanchirico 2010; Altonji et al. 2016; Lowry and Krummenacher 2017; Lowry 2018). As one recent study summarized, "support for open space and public lands in the United States is exceptionally strong for political, cultural, and economic reasons" (Lowry 2018, 1).

Studies that analyze referendum outcomes using aggregated demographic characteristics show policymakers how open space policies play out "where the rubber meets the road." However, an unfortunate characteristic of analysis that uses aggregated data is that it cannot be used to infer relationships on the individual level because the relationship between group correlations and individual correlations can be tenuous (Robinson 1950). Some studies attempt to avoid problems that arise from aggregate data by employing a specific methodology that takes advantage of supplemental aggregate data (King 2013, Cho and Gaines 2004, Coan and Holman 2008) while others avoid the issue altogether by surveying people who voted on a referendum

\footnotetext{
${ }^{1}$ In addition to referendum data being used to assess determinants of support, these data have been used to understand public finance consequences of open space conservation. Lang (2018) finds that passing a municipal open space referendum increases aggregate housing prices, indicating that the amenity value of conservation exceeds the cost in terms of increased taxes.
} 
(e.g. Fischel 1979). However, very few surveys exist of individual attitudes toward open space and no studies that we know of survey voters beyond a single location. ${ }^{2}$

While a handful of studies rely on individual level data to capture the importance of perceptions and opinions on support for environmental policies, each of these studies rely on data from a small geographic unit, sometimes a state but usually a city or metropolitan area. For example, studies investigate how support for open space initiatives and growth management policies correlate with satisfaction with municipality provided services and thinking urban sprawl is a problem (Mohamed 2008), attitudes toward environmental protection and economic growth (Chong and Druckman 2007), residential growth issues (Gerber and Phillips 2005), opinions regarding the importance of water pollution and affordable housing problems (Smutny 1998), and the role of wanting to "escape urban ills" (Gainsborough 2002). These studies typically find that people's perceptions of the consequences of development add explanatory power to their support for open space and growth management policies above and beyond their socioeconomic characteristics. However, these studies rely on surveys of specific locales (e.g. Smutny 1998; Gainsborough 2002; Gerber and Philips 2005; Mohamed 2008) or states or metropolitan areas that have held referenda or implemented "smart growth" policies (e.g. Kline and Wichelns 1994; Howell-Moroney 2004; Solecki, Mason, and Martin 2004; Kline 2006; Kotchen and Powers 2006; Coan and Holman 2008; Schmidt and Paulsen 2009), so it is unclear how generalizable their findings are to individuals across states and communities. We add to the literature by examining how individual level characteristics, including perceptions, opinions, and

\footnotetext{
2 This is not to say that the present study supersedes the cited studies that use aggregated data. State preference studies have been known to suffer from hypothetical bias (Loomis 2011) and not all explanations of environmental policy must be understood through the actions of individuals as opposed to social categories or systems (I.e. methodological individualism) (Arrow 1994). We seek to compliment past studies of determinants of open space referendum preference using different methodological approaches than what has been done before.
} 
demographics, influence open space bond support on a nationally representative sample of respondents. This reduces the chance of bias in our coefficient estimation by ensuring treatment (the proposition of an open space bond) is randomly assigned and not an artifact of spatial correlation where certain community characteristics determine treatment assignment.

Most of our hypotheses derive from the existing studies, however, we expect there may be differences between individual level data and findings derived from aggregate level data primarily because we suspect that the presence of open space referenda may not be random across geographic units. First, land use/growth must be a salient issue in order to make it onto the ballot. And while land use in general may not be a politically salient topic, there must be some sort of significance at least to a threatened piece of land for an interested party to take the time and resources to push for a bond and for a legislature to be responsive to the request enough to place it on the ballot and expend tax dollars for preservation. These are highly likely to be more liberal-leaning and wealthy locations. We suspect this because locations need to be a) willing to prioritize land preservation over economic growth and $b$ ) have the resources available to dedicate tax dollars to preserving the "status quo" (e.g. higher income communities). We do suspect that at the individual level income should have the same effect as found in the aggregate studiesthose with higher income should be more willing to dedicate spending to preserve the status quo because their home values will be preserved or even increased the more land is preserved (e.g. Fischel 2016). However, the literature to date suggests that political ideology has a minimal effect. This may be due to the selection effect. Instead, we suggest that ideology should be a driving motivator of support for land preservation bonds at the individual level.

We also propose a hypothesis untested by the existing literature. Specifically, given the literature to date on community perception, we are not convinced that, in general, actual land use 
will be predictive of support for land preservation bonds. Instead we posit that perceptions of land availability may be more important (Braiser et al 2011). ${ }^{3}$ For one, individuals may have different responses to growth depending on unobserved factors. One might see development that results in land loss as a positive community change if it brings with it wanted services, jobs, amenities or economic growth, whereas another person might see these changes as detrimental to the natural landscape and want to preserve the status quo and stop additional development. And importantly, these two people may perceive the amount of land loss differently. The person who enjoys the development might see the lost land as minimal and believe their community still has "plenty" of open space whereas the person who prioritizes the natural landscape may perceive any land loss as too much and perceive their community as having experienced "a lot" of land loss. Given this, we expect perceptions of the amount of open space to be much more correlated with willingness to pay for land preservation (e.g. support for a bond) than the amount of actual amount of open space. In addition, we think it is likely that the amount of actual land use will only be minimally correlated with the actual amount of open space.

Given our expectations, we test how correlated previously studied variables are with individual level support for open space bonds. These variables include respondents' education, income, political ideology, gender, race, homeownership and age. However, given our expectations, we also investigate how actual vs. perceived land use correlates with citizen support for land preservation bonds.

\section{METHOD}

\subsection{Data}

\footnotetext{
${ }^{3}$ The importance of perception on voting behavior has been tested in topics outside of environmental preferences. For example, see Dyck and Hagley (2012).
} 
In order to test our hypotheses, we conducted a national public opinion poll with YouGov in the fall of 2016. Respondents were selected using a stratified sampling method based on gender, age, race, education, political ideology, political interest, and zip code location within the United States. The survey was designed specifically for this research agenda and with the intention of measuring respondent's support for open space proposals nationwide. Because the term "open space" is likely to trigger a variety of definitions in respondent's minds, before answering questions about their environmental preferences, respondents were first presented with a definition of "open space." We defined "open space" as "a general term used to describe forests, farms, wetlands, recreation areas, parks, and other land that is not developed with buildings or industry." After this definition, respondents were asked: "If you were given the opportunity to vote on a bond measure that would preserve or create open space in your community, how likely would you be to support it?" Respondents could indicate their answer in a four-point Likert scale that included "very unlikely," "somewhat unlikely", "somewhat likely", and "very likely." We utilize this question for our dependent variable.

Because we are interested in how well people's perceptions of the open space in their community correlate with their willingness to support open space preservation efforts, we focus our analysis on several independent variables that measure respondent's perceptions of land use and land use change. ${ }^{4}$ We utilize the question "How much open space would you say your community currently has?" to measure perceived amount of open space in respondents'

\footnotetext{
${ }^{4}$ After answering the dependent variable question, respondents were asked a host of questions on unrelated issues such as minimum wage, gay adoption, etc. before we asked questions that are used as independent variables to decrease the likelihood that respondent's answer to the dependent variable question would alter their answers to the independent variable questions.
} 
communities. Respondents indicated their answers on a five-point Likert scale that included "none", "almost none", "a little", "some", and "a lot."

Second, we measure change in land use in respondents' community by utilizing the question "How has the amount of open space changed in your community over the past 10 years?" Respondents could answer "increased a lot", "increased somewhat", "stayed the same", “decreased somewhat", and "decreased a lot." Because the results utilizing the land use change question are substantively equivalent to the results for the land use amount question, we present here only results using the open space amount question. The models incorporating the open space change question are available in the supplemental appendix.

To test the influence of objective open space measurements, we use land use data from the National Land Cover Database (NLCD) (Homer et al. 2015). The NLCD is a pixelated map of the United States, for years 1992, 2001, 2006, and 2011, where each pixel is assigned a category based on land use type. We define open space as NLCD pixels coded as forest, shrubland, herbaceous, planted/cultivated, and wetlands to correspond to the definition of "open space" provided to respondents in the survey. We use ArcGIS to calculate the percentage of total area that is "open space" in the respondents' zip code and county to proxy for the current amount of open space in their community. ${ }^{5}$

The remaining variables all come from the national survey. These include socioeconomic and demographic characteristics of the respondents including their age, race, sex, income, education and how long they lived in the community. In addition, we include variables for the

\footnotetext{
${ }^{5}$ For the objective measurement of open space change, we used ArcGIS to calculate the percent change in open space pixels in the respondents' zip code and county from 2001 to 2011 to proxy for the change in the amount of open space in the respondents' community in the past 10 years. Results are presented in the appendix.
} 
respondent's level of concern about climate change, the respondent's opinion of the effect open space has on traffic in their community, a factor analysis variable about the respondent's trust in local, state, and federal governments, and a count variable that indicates the number of outdoor activities in which the respondent typically participates. ${ }^{6}$

We use the literature to date that utilizes aggregate data as a guide for our expectations of how these variables should perform. The expected effect that the objective measure of open space on bond support is ambiguous because the literature has shown positive effects (Kline and Wichelns 1994; Howell-Moroney 2004; Gerber and Phillips 2005) and negative effects (Kline and Wichelns 1994; Kotchen and Powers 2006; Banzhaf, Oates, and Sanchirico 2010; Lowry and Krummenacher 2017). For the demographic variables, we expect older respondents (Gainsborough 2002; Howell-Moroney 2004; Kotchen and Powers 2006; Mohamed 2007), women (Gainsborough 2002), people that identify as white (Gainsborough 2002; Romero and Liserio 2002; Howell-Moroney 2004; Mohamed 2007), those with higher education (Gainsborough 2002; Gerber and Philips 2005; Kline 2006; Nelson, Uwasu, and Polaski 2007; Coan and Holman 2008; Banzhaf, Oates, and Sanchirico 2010), and higher income (Gainsborough 2002; Kline 2006; Kotchen and Powers 2006; Nelson, Uwasu, and Polaski 2007; Coan and Holman 2008; Schmidt and Paulsen 2009; Lowry and Krummenacher 2017) to be more likely to support open space bonds. The influence that home ownership has on bond support is also ambiguous as some studies find it increases support (Schmidt and Paulsen 2009; Banzhaf, Oates, and Sanchirico 2010) while others find it decreases support (Kotchen and Powers 2006; Nelson, Uwasu, and Polaski 2007).

\footnotetext{
${ }^{6}$ Exact survey question wording for these variables are included in the appendix.
} 
The influence of political ideology is also ambiguous as studies have found that liberalness both positively influences support (Mohamed 2007; Altonji et al. 2016) and negatively affects support (Lowry and Krummenacher 2017). However, given the high degree of ideological polarization across policy issues and that conservatives are more likely to oppose government intervention in the economy and the taxes that pay for such programs, we expect that those who are more conservative will be less likely to support open space bonds. Trust in government should increase the likelihood of support as government distrust leads voters to vote down initiatives and referenda because distrusters believe that government is unable of giving them what they want (Dyck 2010). We include a variable indicating the respondents' preference for bonds over taxes because several studies have found that open space referenda that are funded by bonds are more likely to pass than those funded by taxes (Kotchen and Powers 2006; Nelson, Uwasu, and Polaski 2007; Lowry and Krummenacher 2017; Lowry 2018).

Although there is no direct comparison to aggregate studies to draw expectations from, we also include variables that capture respondents' concerns about climate change and their opinion of how open space affects traffic in their community as these directly correlate our argument that individuals will respond differently to growth. We believe that those who are already concerned about the environment (e.g. climate change concern) are more likely to support spending to preserve open spaces. In addition, those that perceive negative consequences of growth (e.g. traffic) will be more likely to want to prevent more growth and, as a result, more likely to be supportive of expending resources on land preservation. Formally stated, we expect 
respondents that are more concerned with climate change and those that think open space preservation will reduce traffic to be more likely to support an open space bond. ${ }^{7}$

\subsection{General Methodological Issues}

Our approach to test how objective and subjective measurements of open space contribute to one's willingness to support open space bond referenda is dependent on our ability to attribute objective changes in open space to each survey respondent. In the survey, respondents are asked to indicate how much open space there is within their community. A person's community is a rather subjective term - it could mean anything from a neighborhood to a state or region and anything in between. Many studies have investigated how people define meaning and identity with the area around them (e.g. Gustafson 2001; Cuba and Hummon 1993) and the fact that people define their communities with varying spatial extents (e.g. Coulton Chan, and Mikelbank 2011; Coulton, Jennings, and Chan 2013). With this in mind, we test objective open space measurements at different geographic levels. We calculate open space characteristics at the zip code level (the smallest geographic identifier available in the dataset) and the county level for each respondent to test the effect of objective changes on bond support. ${ }^{8}$

In order to isolate the effect that the objective and subjective measurements of open space in our econometric models, appropriate independent variables must be used to control for other factors that may shape people's preferences for open space bonds. Our approach is to utilize a suite of demographic information at the individual level from our national survey. The issue of multicollinearity, and in turn the reliability of coefficient estimates, can occur if there is a linear

\footnotetext{
${ }^{7}$ Data used in this study will be made available upon request to the authors and via the Harvard Dataverse repository.

${ }^{8}$ We do not calculate open space characteristics at the respondents' state level due to the use of state fixed-effects in our regression models.
} 
relationship between control variables. Tests for redundancy issues within demographic variables in our study reveal most variables do not show symptoms of linear relationships. A respondent's political ideology, however, is moderately correlated with their concern over climate change $(r=$ -0.62). Formal tests for multicollinearity between the demographic variables used in our models indicate that it is not an issue for model estimation. ${ }^{9}$ Moreover, while there is a certain amount of commonality between one's political ideology and attitudes toward climate change, running our econometric models with only one of these variables does not substantively change the results, but results in lower model fit. This indicates that political ideology and concern for climate change, while correlated, each add explanatory power to the models. Given these results, we are comfortable including the full set of demographic and political variables in our econometric analysis.

\subsection{Econometric Approach}

We perform three sets of empirical models to identify the determinants of what influences respondent's perception of community level open space changes and what influences their willingness to support open space referenda. We use ordered logit models as our analytical tool to estimate the effects of independent variables on our categorical dependent variables. First, we estimate the effect of actual open space amounts and changes on likelihood to vote for an open space bond:

$$
\begin{aligned}
& \text { Bond Support }_{\text {ins }}=\beta^{\prime}\left(\text { Objective Measures }_{n}\right)+\delta^{\prime}\left(\text { Demographics }_{i}\right) \\
& +\gamma^{\prime}\left(\text { Opinion }_{i}\right)+\lambda\left(\text { Activities }_{i}\right)+\alpha_{s}+\epsilon_{\text {ins }}
\end{aligned}
$$

\footnotetext{
${ }^{9}$ We test for multicollinearity in our models using variance inflation factor (VIF) analysis. The mean VIF between our demographic variables is 1.28 with a min of 1.03 and a max of 1.73 , well below the rule of thumb value of 10 that warrants further investigation.
} 
where Bond Support ${ }_{\text {ins }}$ is the categorical answer respondent $i$ living in neighborhood $n$ and state $s$ gave to the question "If you were given the opportunity to vote on a bond measure that would preserve or create open space in your community, how likely would you be to support it?" Objective Measures $_{n}$ is a vector of two objectively measured open space variables: amount of open space in 2011 and open space loss between 2001-2011. These are measured at the neighborhood level, which as previously mentioned is subjective. Thus, we estimate this model (and future models) using two different definitions of neighborhood: the respondent's zip code and the respondent's county. Demographics $i$ is a vector of individual level demographic and political variables (including respondent age, income, a five-point scale that indicates their political ideology, and dummy variables that indicate if they are female, white, have a college degree, own a home, live with someone who own or rents, and whether they preferred not to divulge their income level). ${ }^{10}$ Opinion $_{i}$ is a vector of individual variables that examine respondents' concern over climate change, the effect of open space on traffic, and their trust in government. Activities $s_{i}$ is a count variable that indicates how many outdoor activities each respondent participates in. Finally, $\alpha_{s}$ is a state fixed effect that controls for unobservable variables at the state level that may be correlated with amount of open space and bond support. $\beta^{\prime}$ are the parameters of interest in this model and signify the marginal impact objective measures of open space have on the likelihood a respondent will support an open space bond.

\footnotetext{
${ }^{10}$ Many studies of voting use Party Identification instead of ideology, particularly studies utilizing aggregate level data because party voting (e.g. votes for Democrats) can be attained at aggregate levels. Many of these studies also use party voting to represent ideology. In our data, ideology and party identification are correlated at .675. We have tested models using both ideology (as presented here) and party identification and the results are substantively identical. To be consistent with prior individual-level studies in this area, we have elected to present the ideology results.
} 
Before examining the influence that subjective perception has on bond support, we first explore determinants of subjective perception of open space measurements. The estimation equation takes the following form:

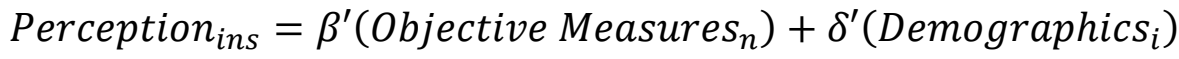

$$
\begin{aligned}
& +\gamma^{\prime}\left(\text { Opinion }_{i}\right)+\lambda\left(\text { Activities }_{i}\right)+\alpha_{s}+\epsilon_{\text {ins }}
\end{aligned}
$$

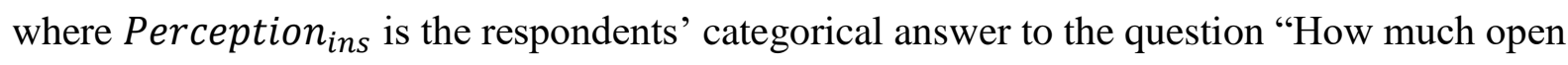
space would you say your community currently has?". Objective Measures $_{n}$, Demographics $_{i}$, Opinion $_{i}$, Activities $_{i}$, and $\alpha_{s}$ are the same as in Equation (1).

Finally, the estimation equation of the effect of perceived open space amount on support for open space bonds takes the following form:

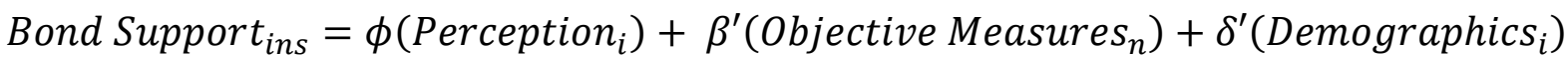

$$
\begin{aligned}
& +\gamma^{\prime}\left(\text { Opinion }_{i}\right)+\lambda\left(\text { Activities }_{i}\right)+\alpha_{s}+\epsilon_{\text {ins }}
\end{aligned}
$$

where $\phi$ is the parameter of interest in this model as it signifies the marginal impact the subjective measure of open space amount has on the likelihood a respondent would support an open space bond.

\section{RESULTS}

\subsection{Bivariate analysis of Role of Perception on Bond Support}

A key novelty of this study is that we can test the importance of people's perception of the environment around them on open space bond preferences. Studies have shown the importance of including subjective measurements in environmental valuation (e.g. Poor et al. 2001; Artell, Ahtiainen, and Pouta 2013). Previous studies that use linear regressions of aggregated land-use data assume that people's awareness or perception of the prevalence of open 
space and the changes to open space over time are constant across and within those geographies. This assumption may not be accurate, however. Figure 1 shows a breakdown of subjective and objective open space measurements that we use in this study. The first panel in the figure shows a histogram of how much open space respondents perceive to be in their community for all respondents. The remaining panels show the distribution of actual open space amounts in the respondents' zip code by open space perception that were represented in the first panel. As hypothesized, the figure shows that there is a lot of variation between what people consider to be "a lot" or "a little" amount of open space and the amount of open space there actually is around them. With a correlation of only 0.14 between the two variables, the bivariate results suggest there are factors other than objective open space measurements that contribute to open space perceptions. The analysis that follows explores the role of open space perception on bond support in a more detailed, multivariate analysis.

[Figure 1 about here]

\subsection{Effect of Objective Open Space Measurements on Bond Support}

Table 1 reports the results of the ordered logit analysis of Equation (1) of the support for bond referenda. Column (1) shows the effects of individual level demographics on the dependent variable. Many of these variables contribute to respondents' preference for open space bonds. Results show that female respondents and white respondents were more likely to support an open space bond. Respondents that own a home are less likely to support an open space bond, a finding that is consistent with the literature on the "renter effect" that finds renters are more likely than homeowners to favor local public expenditures, perhaps because homeowners are more likely than renters to be aware of their tax obligations related to local public spending (Oates 2005, Brunner et. al 2015). 
A few of our results do not support the findings of studies that use aggregate data. As we hypothesized, ideology has a negative coefficient indicating that the more conservative a respondent is, the less likely they are to support an open space bond referendum. This finding is at odds with recent work on open space preservation support that argues that it is divided less by partisan and ideological divisions than other environmental policy issues (Lowry 2018). Almost counterintuitively, respondents that prefer paying for projects with bonds rather than taxes are less likely to support an open space bond. This result is at odds with aggregate studies that find bond funded open space referenda are more likely to pass over those funded by taxes (Kotchen and Powers 2006; Nelson, Uwasu, and Polaski 2007; Lowry and Krummenacher 2017; Lowry 2018). It is hard to justify this result - perhaps respondents that prefer bonds to taxes are more aware of outstanding bonds in their community and would not want to add another, even if it is for an environmental issue. It is worth noting, however, that the statistical significance of the coefficient estimate is lost in later models that control for additional demographic variables (e.g. Columns 4 and 5). Given that the statistical significance of this coefficient estimate is not robust across models, we refrain from drawing strong conclusions and leave investigation of the negative relationship to future research.

[Table 1 about here]

Columns (2) and (3) investigate the effect of objective measures of open space on open space bond support. As described in Section 3.2, we are not able to observe how each respondent defines their "community," so we test the effect of loss of open space over a ten-year period (Open Space Loss) and current level of open space (Total Open Space) in respondents' zip code 
in Column (2) and county in Column (3). ${ }^{11}$ Coefficient estimates for these variables at both the zip code and county levels are statistically insignificant which suggests that actual changes in and levels of open space immediately surrounding the respondent does not have a consistent effect on their land use preferences.

Column (4) and Column (5) in Table 2 reproduce the regressions from Column (2) and Column (3) with the addition of variables measuring environmental policy opinions and outdoor activities. Results indicate the importance of including these individual covariates in explaining open space bond support. Both the Climate Change Concern and Outdoor Activities variables have statistically significant and positive coefficient estimates indicating the more concerned with climate change a respondent is and the more outdoor activities they participate in, the more likely they are to support an open space bond. The coefficient estimate on Open Space Traffic indicates that the more a respondent believes open space preservation will decrease [increase] traffic in their community, the more [less] likely they are to vote in favor of an open space bond. For the most part, the inclusion of the opinion and activity variables does not change the significance of the objective measurements and demographics; and importantly, objective measures of land use remain insignificant.

\subsection{Determinants of Subjective Open Space Perception}

Table 2 reports the results of the ordered logit analysis of Equation (2). Column (1) shows the effect individual level demographics have on respondents' perception of the amount of

\footnotetext{
${ }^{11}$ Previous studies use a variety of units to investigate support for open space. Gerber and Phillips (2005) use cities/municipalities, Banzhaf, Oates, and Sanchirico (2010) use municipalities and counties, Howell-Moroney (2004) and Nelson, Uwasu, and Polaski (2007) use municipalities, Kline and Wichelns (1994) use counties, cities, and towns, Kotchen and Powers (2006) use states, counties, and municipalities, Lowry and Krummenacher (2017) use states and local communities, Lowry (2018) uses states, and Altonji et al. (2016) use precincts in a statewide referendum.
} 
open space there is in their community. Results show that female respondents are more likely to indicate a smaller amount of open space in their community, while respondents that are older (only at the $10 \%$ significance level), respondents with a bachelor's degree or higher, and those with higher income are more likely to perceive a larger amount of open space in their community.

\section{[Table 2 about here]}

Column (2) and Column (3) reproduce the results of Column (1), but add objective measurements of open space loss and the total amount of open space that was measured in the respondents' zip code and county, respectively. These results show that objective open space measurements do influence people's perception of open space amounts in their community. Column (2) shows that respondents with a higher percentage of open space in their zip code are more likely to perceive more open space in their community. Column (3) examines this relationship using county level objective open space measurements and shows that respondents that live in counties with a high amount of open space loss over a 10-year period are more likely to indicate a small amount of open space in their community. Again, the coefficient for Total Open Space shows that respondents that live in counties with more open space perceive more open space in their community, but the model fit is higher when measuring at the zip code level.

Column (4) and Column (5) add in the opinion variables and outdoor activity variable. Respondents that are concerned about climate change perceive less open space in their communities (though only at the $10 \%$ significance level), while respondents that trust their government perceive more open space in their communities. Overall, the results of Table 2 show that there is a correlation between objective measurements of open space around survey 
respondents and their subjective perception of how much open space is in their community. ${ }^{12}$

However, this perception is also influenced by individual level demographics and opinions.

Next, we test whether this subjective perception variable influences open space bond support.

\subsection{Effect of Subjective Perception of Open Space on Bond Support}

Table 3 reports the results of the ordered logit analysis of Equation (3). These results show the importance of the perception of open space amount in a respondent's community on their likelihood to support an open space bond referendum. Columns (1) to (5) show the robustness of the perception of open space amount coefficient to testing actual levels and loss in open space measured at the zip code and county level (Columns 2 and 3) and the inclusion of individual opinion and activity variables (Columns 4 and 5). The negative sign of the perception coefficient suggests the more open space a respondent perceives in their community, the less likely they are to vote in favor of an open space bond referendum, regardless of actual open space changes and levels around them. In this case, people may think there is enough open space in their community and would rather spend public funds on other resources or programs.

Conversely, people that think there is not a lot of open space in their community appear more likely to support an open space bond to protect what they perceive as the limited open space available in their community. Importantly, while actual open space is limitedly related to open space perception, only perception of open space is statistically related to support for an open

\footnotetext{
${ }^{12}$ Results for determinants of respondents' perception of open space change in their community is similar to the results about the perception of open space amount. Determinants of open space change perception are the objective measurement of open space loss, gender, race, the number of years the respondent has lived in their community, opinion about how open space affects traffic, and government trust. Results are presented in the appendix.
} 
space preservation bond. ${ }^{13}$ Tables 1 and 3 show that adding individual opinion, activity, and

open space perception variables improve the explanatory power of our econometric models. ${ }^{14}$

[Table 3 about here]

\subsection{Marginal Effects}

To better understand the magnitudes associated with our independent variables on the likelihood a respondent supports open space bonds, we present marginal effects for the model in Column (5) of Table 3. Figure 2 presents these marginal effects visually. The top left panel in Figure 2 shows the marginal effects of each category of open space perception on being very likely to support an open space bond. For example, a respondent that has the perception that there is no open space in their community has about a $60 \%$ probability of being very likely to support a bond, whereas those who said their community has "a lot" of open space had a

\footnotetext{
${ }^{13}$ Results that use the perception of open space change as a determinant of bond support are similar to the ones presented in the main text where respondents that perceive more open space loss in their community are more likely to support an open space bond. Results are presented in the appendix.

${ }^{14}$ While Model fit remains low, that is to be expected. One of the unique contributions of our study is the elicitation of open space preferences from a randomly selected national sample as opposed to non-randomly-selected areas where land use planning is a prominent issue or in which there is currently a question regarding land planning on the ballot. This is important for generalizable conclusions, but it also increases the probability that some respondents live in areas in which land use is not a salient issue. This, in turn, can lead to less consistent preferences and lower pseudo R-squared because this is an issue that respondents have not been privy to political discussions regarding the role of government in preserving land or the need to do so (or not). To address this potential, we re-estimate the models in Table 3's Columns 3 and 4 on a subset of respondents from areas that have recently experienced high increases in development to see if individuals in these areas have more constrained views. People in these areas may be more aware of development issues and have more consistent preferences for open space referendums. Results are shown in Table A3 in the appendix. Both models show a noticeable increase in model fit (pseudo R-squared of 0.264 and 0.262 ). Though model fit increases on the high development growth observations, we prefer the models presented in Table 3 because they show that results are robust to the inclusion of a nationally representative sample. What is most important is that perception of growth continues to be strongly correlated with support for bonds. In addition, the other variables that show the largest correlation with support for an open space bond are the opinion measures including political ideology, views of climate change, concern over traffic and outdoor actives. This robustness check suggests that our models have good explanatory power but that land use is not salient in all locations in the U.S and therefore public opinion will have a large error term because people do not have welldeveloped opinions about issues that are not on the current political agenda (e.g. Zaller 1994).
} 
probability of $46 \%$, a reduction of 14 percentage points for the full range of the variable. A respondent's perception of the amount of open space in their community can have a big impact on their open space bond preferences. Similar findings are found for political ideology and the expectation of how open space affects traffic where the probability of being very likely to support an open space bond decreases by about 18 percentage points between very conservative respondents and very liberal respondents and by about 14 percentage points across the full range of the traffic concern variable. The probability of being very likely to support an open space bond is 8 percentage points higher for people that are white compared to non-whites and increases by about 45 percentage points for people that are very concerned about climate change compared to those that are not. Finally, those who participate in the maximum number of outside activities observed in our data (6) have a 25 percentage point greater chance of supporting a bond compared to those who participate in no outside activities.

[Figure 2 about here]

\section{DISCUSSION}

We have demonstrated the importance of eliciting individual perceptions, opinions, and activities when analyzing preferences for open space bond referenda. We find that perceptions of the amount of open space in one's community is an important explanatory variable in determining the likelihood of supporting an open space bond, more so than objective measures of open space. This makes sense as people's responses to growth are not uniform — some find growth to be a welcome sign of progress and economic prosperity whereas others view growth as an unwelcome change to the natural landscape and the community's character and as a result people's views of how much land has been lost may be contingent upon how they view the effects of development. 
We also find that along with individual demographic and policy concerns, objective measurements of open space amount influence a person's perception of open space in their community. This is an important addition to the literature where the role of individual perceptions on curbing development has focused more on attitudes towards development and urban sprawl than on support for open space, whereas the literature on open space bond support has largely been case specific or utilized only aggregate results generated from comparing places that held open space referenda.

By investigating individual preferences for open space bond referenda, we can investigate how well individual characteristics line up with the previous literature that typically uses aggregated demographic data. Our findings differ from those that cite the importance of controlling for objective levels of and changes in open space (Kline and Wichelns 1994; HowellMoroney 2004; Gerber and Phillips 2005; Kotchen and Powers 2006; Nelson, Uwasu, and Polaski 2007; Banzhaf, Oates, and Sanchirico 2010) except to the small extent of which these objective measures inform individual perceptions as we presented above. In none of our bond support models did objectively measured current levels of open space or loss of open space in a 10-year period show statistically significant coefficient estimates.

Our results indicate that only a few individual level demographic variables are associated with support for government open space preservation efforts. Of these variables, only race, home ownership, and political ideology are investigated in aggregated studies. Our results support the findings of several aggregate studies that show that areas with a higher percentage of residents that are white are more likely to support anti-growth measures (Romero and Liserio 2002, Howell-Moroney 2004). The influence home ownership has on open space referenda is ambiguous in the literature, however our findings support those that observe a negative 
relationship (Kotchen and Powers 2006, Nelson, Uwasu, and Polaski 2007). Our results also support the findings of aggregated studies that measure political indicators where areas that are more Republican or conservative are less likely to support environmental referenda (Nelson, Uwasu, and Ploaski 2007; Coan and Holman 2008; Lowry and Krummenacher 2017). Interestingly, our individual-level results do not support some of the aggregate level studies that claim important determinants of environmental referendum support include individual's levels of education (Gerber and Phillips 2005; Kline 2006; Nelson, Uwasu, and Polaski 2007; Coan and Holman 2008; Banzhaf, Oates, and Sanchirico 2010; Allen et al. 2013) and income (Solecki, Mason, and Martin 2004; Gerber and Phillips 2005; Kline 2006; Kotchen and Powers 2006; Nelson, Uwasu, and Polaski 2007; Coan and Holman 2008; O’Connell 2008; Schmidt and Paulsen 2009; Allen et al. 2013; Lowry and Krummenacher 2017). It is possible that significant coefficients from these studies result from spatial correlations that occur from self-selected observations or the tenuous relationship between aggregate correlations and individual preferences, but further research would be needed to conclude so.

We can also compare our results with studies that examine individual preferences for land conservation and land use policy to test how generalizable their findings are. We find both similarities and differences between our nationally-representative study and those that focus on a limited geographic area. Our finding that opinion on environmental issues is an important determinant of open space and development preferences reinforces the findings by Smutny (1998) as well as Mohamed (2008). Our results also agree with studies that show that age, race, and ideology are important determinants of open space and development preferences (e.g. Kline and Wichelns 1998; Mcleod, Woirhaye, and Menkhaus 1999; Gainsborough 2002; Mohamed 2008). Not all of our results agree with case studies that are conducted in limited geographic 
ranges, however. We do not find that education, income, gender, or duration of residency play important roles in open space bond support unlike others in the literature (e.g. Mcleod, Woirhaye, and Menkhaus 1999; Gainsborough 2002; Naheulhaul, Loureiro, and Loomis 2004; Cho, Newman, and Bowker 2005).

\section{CONCLUSION}

This study investigates the individual and aggregate level correlates of support for open space referenda to identify the importance of individual perceptions of community open space on land use policy support. We make two main contributions to the literature. First, we elicit open space bond preferences from a nationally-representative random sample of respondents. This holds important implications for the generalizability of analysis results as opposed to studies that analyze open space referenda in communities that have self-selected for treatment. Second, we believe we are the first to compare the roles individual perceptions and objective measures of open space play in preferences for bond referenda.

We find that actual levels of open space and population density are statistically correlated with perceptions of community level open space changes. Our findings are a departure from the literature because we find this perception of community open space is more influential in determining bond support than objective open space measurements and many demographic variables that are included in aggregated studies are not statistically significant at the individual level. We show people's perception of open space in their community is a better predictor of individual bond support. In addition, we also add to the literature by showing how other opinions affect the likelihood of voting to protect land including concern over climate change and attitudes about the effect of growth on daily quality of life (measured as concern about traffic). 
Though secondary to our main contributions, our results may have implications for policymakers and advocates that want to conserve land in communities. Our results suggest that the success of land conservation policy advocates does not have to be determined by the selection of communities for policy focus across space, but the probability of success may be able to be increased within any community through changing perceptions about open space resources. What is unclear, however, is whether perception influences bond support through accuracy of subjective open space measurements with reality (where advocates should focus on making actual amounts and changes in open space clearer) or through the consequences of open space preservation (where advocates should focus on emphasizing how current amounts and changes in open space affects the community - such as increasing traffic congestion). The statistical significance and large marginal impacts of the opinion variables about climate change concern and expected impact of open space on traffic suggest the decision-making of respondents is being driven by idiosyncratic expectations of the consequences of open space preservation. We are unable to test this relationship with our current data, however, and suggest it for future research. 


\section{REFERENCES}

Allen, Stephen, et al. "Predicting success incorporating conservation subdivisions into land use planning." Land use policy 33 (2013): 31-35.

Arrow, Kenneth J. "Methodological individualism and social knowledge." The American Economic Review 84.2 (1994): 1-9.

Artell, Janne, Heini Ahtiainen, and Eija Pouta. "Subjective vs. objective measures in the valuation of water quality." Journal of environmental management 130 (2013): 288-296.

Altonji, Matthew, Corey Lang, and Gavino Puggioni. "Can urban areas help sustain the preservation of open space? Evidence from statewide referenda." Ecological Economics 130 (2016): 82-91.

Banzhaf, H. Spencer, Wallace E. Oates, and James N. Sanchirico. "Success and design of local referenda for land conservation." Journal of Policy Analysis and Management 29.4 (2010): 769-798.

Baranzini, Andrea, Caroline Schaerer, and Philippe Thalmann. "Using measured instead of perceived noise in hedonic models." Transportation Research Part D: Transport and Environment 15.8 (2010): 473-482.

Brenner, Jacob C., et al. "Land use determines interest in conservation easements among private landowners." Land Use Policy 35 (2013): 24-32.

Brunner, Eric, and Jon Sonstelie. "Homeowners, property values, and the political economy of the school voucher." Journal of Urban Economics 54.2 (2003): 239-257.

Cho, Tam, K., Wendy, and Gaines, Brian J. "The Limits of Ecological Inference: The Case of Split-Ticket Voting." American Journal of Political Science 48.1 (2004): 152-171.

Cho, Seong-Hoon, David H. Newman, and J. Michael Bowker. "Measuring rural homeowners' willingness to pay for land conservation easements." Forest Policy and Economics 7.5 (2005): 757-770.

Chong, Dennis, and James N. Druckman. "Framing public opinion in competitive democracies." American Political Science Review 101.4 (2007): 637-655.

Coan, Travis G., and Mirya R. Holman. "Voting green." Social Science Quarterly 89.5 (2008): 1121-1135.

Coulton, Claudia, Tsui Chan, and Kristen Mikelbank. "Finding place in community change initiatives: Using GIS to uncover resident perceptions of their neighborhoods." Journal of Community Practice 19.1 (2011): 10-28.

Coulton, Claudia J., M. Zane Jennings, and Tsui Chan. "How big is my neighborhood? Individual and contextual effects on perceptions of neighborhood scale." American Journal of Community Psychology 51.1-2 (2013): 140-150. 
Cuba, Lee, and David M. Hummon. "A place to call home: Identification with dwelling, community, and region." The sociological quarterly 34.1 (1993): 111-131.

Daams, Michiel N., Frans J. Sijtsma, and Arno J. van der Vlist. "The effect of natural space on nearby property prices: accounting for perceived attractiveness." Land Economics 92.3 (2016): 389-410.

Deacon, Robert, and Perry Shapiro. "Private preference for collective goods revealed through voting on referenda." The American Economic Review (1975): 943-955.

Dyck, Joshua J. "Political distrust and conservative voting in ballot measure elections." Political Research Quarterly 63.3 (2010): 612-626.

Dyck, Joshua J., and Annika Hagley. "Political geography, direct democracy, and the reasoning voter: spatial proximity, symbolic politics, and voting on California's Proposition 83." Politics \& Policy 40.2 (2012): 195-220.

Fischel, William A. "Determinants of voting on environmental quality: a study of a New Hampshire pulp mill referendum." Journal of Environmental Economics and Management 6.2 (1979): 107-118.

Fischel, William A. "The Rise of the Homevoters: How the Growth Machine Was Subverted by OPEC and Earth Day." In Evidence and Innovation In Housing Law and Policy, edited by Lee Anne Fennell, Benjamin J. Keys. (2016): 13.

Gainsborough, Juliet F. "Slow growth and urban sprawl: Support for a new regional agenda?" Urban Affairs Review 37.5 (2002): 728-744.

Gerber, Elisabeth R., and Justin H. Phillips. "Evaluating the effects of direct democracy on public policy: California's urban growth boundaries." American Politics Research 33.2 (2005): 310-330.

Gustafson, Per. "Meanings of place: Everyday experience and theoretical conceptualizations." Journal of environmental psychology 21.1 (2001): 5-16.

Homer, C.G., Dewitz, J.A., Yang, L., Jin, S., Danielson, P., Xian, G., Coulston, J., Herold, N.D., Wickham, J.D., and Megown, K., 2015, Completion of the 2011 National Land Cover Database for the conterminous United States-Representing a decade of land cover change information. Photogrammetric Engineering and Remote Sensing, v. 81, no. 5, p. 345-354

Howell-Moroney, Michael. "Community characteristics, open space preservation and regionalism: Is there a connection?" Journal of Urban Affairs 26.1 (2004): 109-118.

Kahn, Matthew E., and John G. Matsusaka. "Demand for environmental goods: Evidence from voting patterns on California initiatives." The Journal of Law and Economics 40.1 (1997): 137-174.

King, Gary. A solution to the ecological inference problem: Reconstructing individual behavior from aggregate data. Princeton University Press, 2013. 
Kline, Jeffrey D. "Public demand for preserving local open space." Society and Natural Resources 19.7 (2006): 645-659.

Kline, Jeffrey, and Dennis Wichelns. "Measuring heterogeneous preferences for preserving farmland and open space." Ecological Economics 26.2 (1998): 211-224.

Kline, Jeffrey, and Dennis Wichelns. "Using referendum data to characterize public support for purchasing development rights to farmland." Land Economics (1994): 223-233.

Kotchen, Matthew J., and Shawn M. Powers. "Explaining the appearance and success of voter referenda for open-space conservation." Journal of Environmental Economics and Management 52.1 (2006): 373-390.

Lang, Corey. "Assessing the efficiency of local open space provision." Journal of Public Economics 158 (2018): 12-24.

Loomis, John. "What's to know about hypothetical bias in stated preference valuation studies?." Journal of Economic Surveys 25.2 (2011): 363-370.

Lowry, W. R. (2018), "The Exceptionalism of the Open Space Issue in American Politics". Social Science Quarterly. Published on-line ahead of print 26 February 2018. Available at: https://onlinelibrary.wiley.com/doi/abs/10.1111/ssqu.12499

Lowry, William R., and W. Scott Krummenacher. "Coalitions and Conservation: Conditional Impacts of Coalitions on Ballot Measures for Open Space." Review of Policy Research 34.3 (2017): 357-377.

McLeod, Donald M., Jody Woirhaye, and Dale J. Menkhaus. "Factors influencing support for rural land use control: A case study." Agricultural and Resource Economics Review 28.1 (1999): 44-56.

Mínguez, Román, José-María Montero, and Gema Fernández-Avilés. "Measuring the impact of pollution on property prices in Madrid: objective versus subjective pollution indicators in spatial models." Journal of Geographical Systems 15.2 (2013): 169-191.

Mohamed, Rayman. "Who would pay for rural open space preservation and inner-city redevelopment? Identifying support for policies that can contribute to regional land use governance." Urban Studies 45.13 (2008): 2783-2803.

Nelson, Erik, Michinori Uwasu, and Stephen Polasky. "Voting on open space: What explains the appearance and support of municipal-level open space conservation referenda in the United States?" Ecological Economics 62.3 (2007): 580-593.

Oates, Wallace E. "Property taxation and local public spending: the renter effect." Journal of Urban Economics 57.3 (2005): 419-431.

O'Connell, Lenahan. "Exploring the social roots of smart growth policy adoption by cities." Social Science Quarterly 89.5 (2008): 1356-1372. 
Poor, P. Joan, et al. "Objective versus subjective measures of water clarity in hedonic property value models." Land Economics 77.4 (2001): 482-493.

Robinson, WS. "Ecological Correlations and the Behavior of Individuals." American Sociological Review 15.3 (1950): 351-357.

Romero, Francine, and Adrian Liserio. "Saving open spaces: determinants of 1998 and 1999 “antisprawl” ballot measures." Social Science Quarterly 83.1 (2002): 341-352.

Schmidt, Stephan, and Kurt Paulsen. "Is open-space preservation a form of exclusionary zoning? The evolution of municipal open-space policies in New Jersey." Urban Affairs Review 45.1 (2009): 92-118.

Smutny, Gayla. "Legislative support for growth management in the Rocky Mountains: An exploration of attitudes in Idaho." Journal of the American Planning Association 64.3 (1998): 311-323.

Solecki, William D., Robert J. Mason, and Shannon Martin. "The Geography of Support for Open-Space Initiatives: A Case Study of New Jersey's 1998 Ballot Measure." Social Science Quarterly 85.3 (2004): 624-639. 
Figure 1: Breakdown of Subjective and Objective Variables
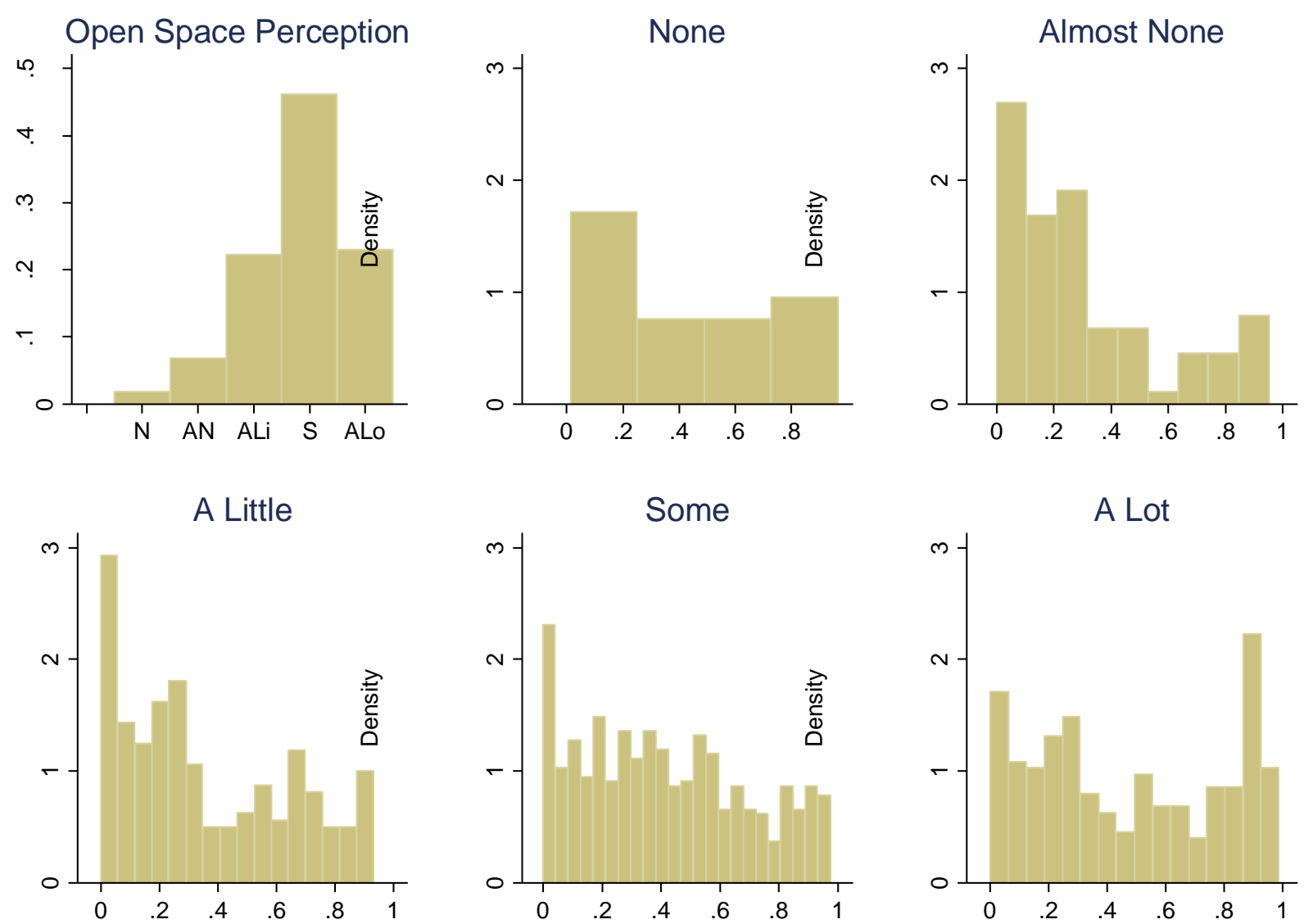

Notes: Graphs show a breakdown of subjective and objective open space measurements that we use in this study. The first panel in the figure shows a histogram of how much open space respondents perceive to be in their community for all respondents. The rest of the panels show the distribution of actual open space amounts in the respondents' zip code by open space perception that were represented in the first panel. The $\mathrm{Y}$ axis ranges represents the density of responses or respondent open space amount characteristic. In the OS Perception panel, N represents "None", AN represents "Almost None", ALi represents "A Little", S represents "Some", and ALo represents "A Lot." The X-axis in panels 2-6 are proportions of the respondents' zip code that is open space land. 
Figure 2: Marginal Effects of Explanatory Variables on Open Space Bond Support
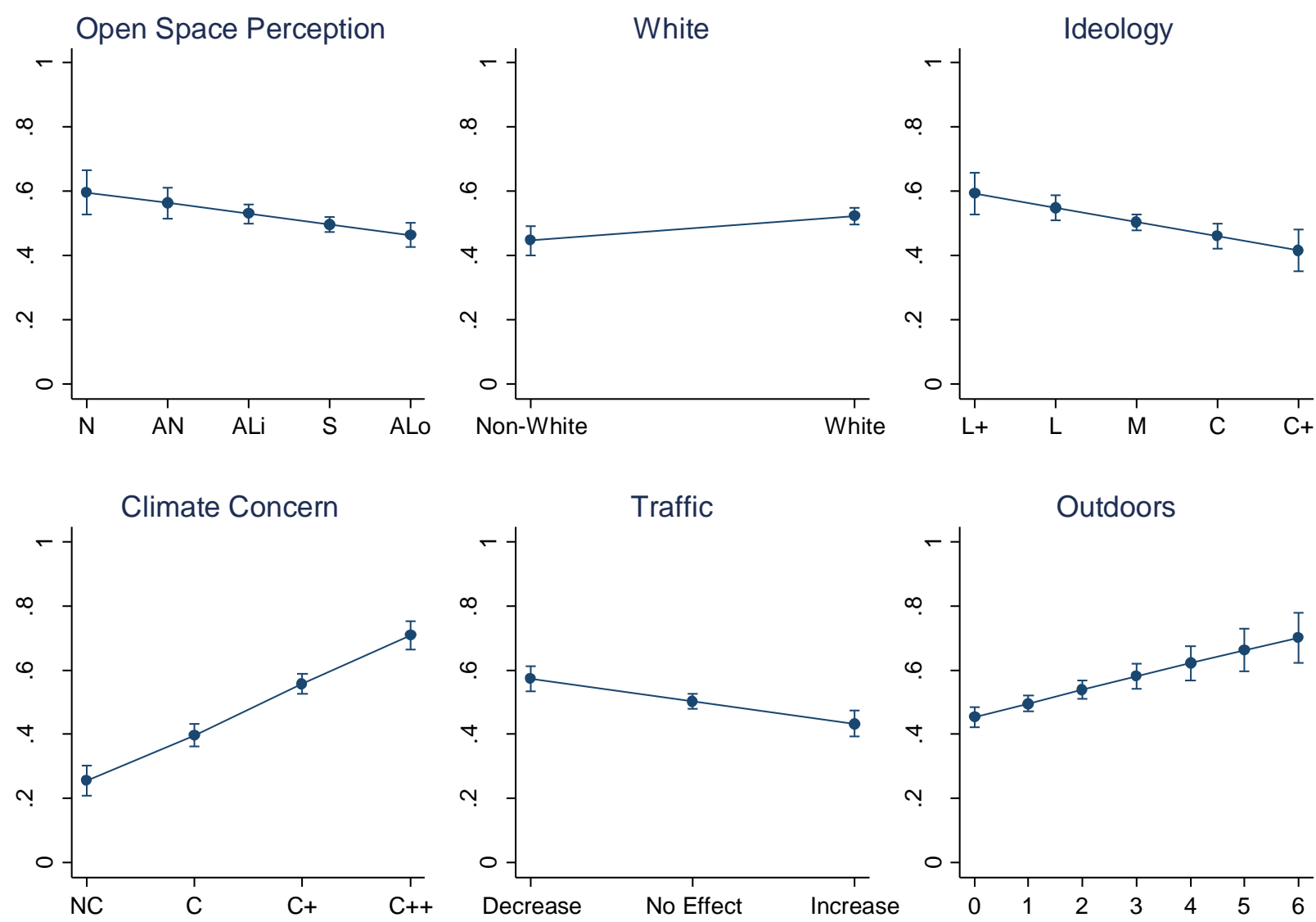

Notes: Graphs show marginal effects at specified values for independent variables. The $\mathrm{Y}$ axis represents the probability that a respondent is strongly in favor of supporting a bond referendum. In the Open Space Perception panel, N represents "None", AN represents "Almost None", ALi represents "A Little", S represents "Some", and ALo represents "A Lot." In the Ideology panel, L+ represents "Very Liberal", L represents "Liberal", M represents "Moderate", C represents

"Conservative", and C+ represents "Very Conservative." In the Climate Concern panel, NC represents "Not at all concerned", C represents "A little concerned", $\mathrm{C}+$ represents "Somewhat Concerned", and C++ represents "Very concerned." 
Table 1: Effect of Objective Open Space Measurements on Bond Support

\begin{tabular}{|c|c|c|c|c|c|}
\hline VARIABLES & $\begin{array}{c}\text { (1) } \\
\text { Bond } \\
\text { Support }\end{array}$ & $\begin{array}{c}(2) \\
\text { Bond } \\
\text { Support }\end{array}$ & $\begin{array}{c}(3) \\
\text { Bond } \\
\text { Support }\end{array}$ & $\begin{array}{c}(4) \\
\text { Bond } \\
\text { Support }\end{array}$ & $\begin{array}{c}(5) \\
\text { Bond } \\
\text { Support }\end{array}$ \\
\hline \multicolumn{6}{|l|}{ Objective Measures } \\
\hline Open Space Loss & & $\begin{array}{c}0.572 \\
(0.396)\end{array}$ & $\begin{array}{l}-0.164 \\
(0.516)\end{array}$ & $\begin{array}{c}0.402 \\
(0.413)\end{array}$ & $\begin{array}{c}0.124 \\
(0.537)\end{array}$ \\
\hline Total Open Space & & $\begin{array}{l}0.0900 \\
(0.220)\end{array}$ & $\begin{array}{l}-0.420 \\
(0.341)\end{array}$ & $\begin{array}{l}0.0756 \\
(0.230)\end{array}$ & $\begin{array}{l}-0.414 \\
(0.357)\end{array}$ \\
\hline \multicolumn{6}{|l|}{ Demographics } \\
\hline Age & $\begin{array}{l}0.00795 * \\
(0.00424)\end{array}$ & $\begin{array}{l}0.00767 * \\
(0.00424)\end{array}$ & $\begin{array}{l}0.00782 * \\
(0.00425)\end{array}$ & $\begin{array}{c}0.00939 * * \\
(0.00447)\end{array}$ & $\begin{array}{c}0.00959 * * \\
(0.00447)\end{array}$ \\
\hline Female & $\begin{array}{c}0.300 * * \\
(0.118)\end{array}$ & $\begin{array}{c}0.297 * * \\
(0.118)\end{array}$ & $\begin{array}{c}0.295 * * \\
(0.118)\end{array}$ & $\begin{array}{c}0.223^{*} \\
(0.123)\end{array}$ & $\begin{array}{c}0.224 * \\
(0.123)\end{array}$ \\
\hline White & $\begin{array}{c}0.331 * * \\
(0.143)\end{array}$ & $\begin{array}{c}0.326 * * \\
(0.144)\end{array}$ & $\begin{array}{c}0.348 * * \\
(0.144)\end{array}$ & $\begin{array}{c}0.386 * * * \\
(0.150)\end{array}$ & $\begin{array}{c}0.417 * * * \\
(0.149)\end{array}$ \\
\hline College or Higher & $\begin{array}{l}0.0546 \\
(0.123)\end{array}$ & $\begin{array}{c}0.0457 \\
(0.124)\end{array}$ & $\begin{array}{l}0.0502 \\
(0.123)\end{array}$ & $\begin{array}{c}-0.0909 \\
(0.129)\end{array}$ & $\begin{array}{c}-0.0846 \\
(0.128)\end{array}$ \\
\hline Owns a House & $\begin{array}{c}-0.336 * * \\
(0.158)\end{array}$ & $\begin{array}{c}-0.353 * * \\
(0.159)\end{array}$ & $\begin{array}{c}-0.327 * * \\
(0.158)\end{array}$ & $\begin{array}{c}-0.373 * * \\
(0.167)\end{array}$ & $\begin{array}{c}-0.356^{* *} \\
(0.166)\end{array}$ \\
\hline Live with Someone & $\begin{array}{c}0.105 \\
(0.215)\end{array}$ & $\begin{array}{l}0.0935 \\
(0.215)\end{array}$ & $\begin{array}{c}0.120 \\
(0.215)\end{array}$ & $\begin{array}{l}-0.0404 \\
(0.223)\end{array}$ & $\begin{array}{l}-0.0188 \\
(0.223)\end{array}$ \\
\hline Income (midpoints) & $\begin{array}{c}0.00145 \\
(0.00123)\end{array}$ & $\begin{array}{c}0.00130 \\
(0.00123)\end{array}$ & $\begin{array}{c}0.00132 \\
(0.00123)\end{array}$ & $\begin{array}{l}0.000149 \\
(0.00124)\end{array}$ & $\begin{array}{l}-2.55 \mathrm{e}-07 \\
(0.00123)\end{array}$ \\
\hline $\begin{array}{l}\text { Prefer not to Answer } \\
\text { Income }\end{array}$ & $\begin{array}{l}-0.0295 \\
(0.193)\end{array}$ & $\begin{array}{l}-0.0492 \\
(0.194)\end{array}$ & $\begin{array}{l}-0.0335 \\
(0.194)\end{array}$ & $\begin{array}{l}0.0368 \\
(0.201)\end{array}$ & $\begin{array}{l}0.0335 \\
(0.201)\end{array}$ \\
\hline Lived in Community & $\begin{array}{l}-0.00664 \\
(0.0555)\end{array}$ & $\begin{array}{c}-0.000937 \\
(0.0556)\end{array}$ & $\begin{array}{l}-0.00473 \\
(0.0556)\end{array}$ & $\begin{array}{c}0.0167 \\
(0.0576)\end{array}$ & $\begin{array}{c}0.0175 \\
(0.0576)\end{array}$ \\
\hline Prefer Bonds over Taxes & $\begin{array}{l}-0.301 * * \\
(0.132)\end{array}$ & $\begin{array}{c}-0.310 * * \\
(0.132)\end{array}$ & $\begin{array}{c}-0.299 * * \\
(0.133)\end{array}$ & $\begin{array}{l}-0.204 \\
(0.139)\end{array}$ & $\begin{array}{l}-0.198 \\
(0.139)\end{array}$ \\
\hline Ideology (5-point) & $\begin{array}{l}-0.653 * * * \\
(0.0570)\end{array}$ & $\begin{array}{c}-0.658 * * * \\
(0.0572)\end{array}$ & $\begin{array}{l}-0.649 * * * \\
(0.0571)\end{array}$ & $\begin{array}{c}-0.245 * * * \\
(0.0678)\end{array}$ & $\begin{array}{c}-0.236 * * * \\
(0.0678)\end{array}$ \\
\hline
\end{tabular}


Table 1: (Continued)

\begin{tabular}{|c|c|c|c|c|c|}
\hline Opinion & & & & & \\
\hline Climate Change Concern & & & & $\begin{array}{c}0.739 * * * \\
(0.0684)\end{array}$ & $\begin{array}{c}0.742 * * * \\
(0.0686)\end{array}$ \\
\hline Open Space Traffic & & & & $\begin{array}{c}-0.373 * * * \\
(0.0919)\end{array}$ & $\begin{array}{c}-0.371 * * * \\
(0.0919)\end{array}$ \\
\hline Government Trust (factor) & & & & $\begin{array}{c}0.0650 \\
(0.0661)\end{array}$ & $\begin{array}{c}0.0631 \\
(0.0662)\end{array}$ \\
\hline Activities & & & & & \\
\hline Outdoors & & & & $\begin{array}{c}0.225 * * * \\
(0.0509)\end{array}$ & $\begin{array}{c}0.233 * * * \\
(0.0511)\end{array}$ \\
\hline Observations & 1,237 & 1,237 & 1,237 & 1,237 & 1,237 \\
\hline Neighborhood & N/A & Zip & County & Zip & County \\
\hline State FE & Yes & Yes & Yes & Yes & Yes \\
\hline Pseudo R-squared & 0.100 & 0.101 & 0.101 & 0.170 & 0.170 \\
\hline
\end{tabular}

Notes: Regressions are ordered logit estimates with likelihood of supporting a bond measure that would preserve or create open space as the dependent variable. Standard errors are in parentheses; $* p<0.1, * * p<0.05, * * * p<0.01$. 
Table 2: Determinants of Perception of Open Space Amount

\begin{tabular}{|c|c|c|c|c|c|}
\hline VARIABLES & $\begin{array}{c}(1) \\
\text { Open } \\
\text { Space } \\
\text { Amount }\end{array}$ & $\begin{array}{c}(2) \\
\text { Open } \\
\text { Space } \\
\text { Amount }\end{array}$ & $\begin{array}{c}(3) \\
\text { Open } \\
\text { Space } \\
\text { Amount }\end{array}$ & $\begin{array}{c}(4) \\
\text { Open } \\
\text { Space } \\
\text { Amount }\end{array}$ & $\begin{array}{c}\text { (5) } \\
\text { Open Space } \\
\text { Amount }\end{array}$ \\
\hline \multicolumn{6}{|l|}{ Objective Measures } \\
\hline Open Space Loss & & $\begin{array}{l}-0.489 \\
(0.370)\end{array}$ & $\begin{array}{c}-1.052 * * \\
(0.483)\end{array}$ & $\begin{array}{l}-0.448 \\
(0.371)\end{array}$ & $\begin{array}{c}-1.145 * * \\
(0.486)\end{array}$ \\
\hline Total Open Space & & $\begin{array}{c}1.118 * * * \\
(0.211)\end{array}$ & $\begin{array}{c}0.796 * * \\
(0.312)\end{array}$ & $\begin{array}{c}1.124 * * * \\
(0.211)\end{array}$ & $\begin{array}{c}0.760 * * \\
(0.313)\end{array}$ \\
\hline \multicolumn{6}{|l|}{ Demographics } \\
\hline Age & $\begin{array}{l}0.00672 * \\
(0.00395)\end{array}$ & $\begin{array}{l}0.00737 * \\
(0.00397)\end{array}$ & $\begin{array}{l}0.00680 * \\
(0.00396)\end{array}$ & $\begin{array}{c}0.00807 * * \\
(0.00402)\end{array}$ & $\begin{array}{l}0.00748 * \\
(0.00401)\end{array}$ \\
\hline Female & $\begin{array}{c}-0.268 * * \\
(0.109)\end{array}$ & $\begin{array}{c}-0.274 * * \\
(0.110)\end{array}$ & $\begin{array}{c}-0.261 * * \\
(0.110)\end{array}$ & $\begin{array}{c}-0.244 * * \\
(0.111)\end{array}$ & $\begin{array}{c}-0.231 * * \\
(0.111)\end{array}$ \\
\hline White & $\begin{array}{c}0.190 \\
(0.135)\end{array}$ & $\begin{array}{l}0.0958 \\
(0.136)\end{array}$ & $\begin{array}{c}0.120 \\
(0.136)\end{array}$ & $\begin{array}{l}0.0948 \\
(0.136)\end{array}$ & $\begin{array}{c}0.118 \\
(0.136)\end{array}$ \\
\hline College or Higher & $\begin{array}{c}0.409 * * * \\
(0.114)\end{array}$ & $\begin{array}{c}0.447 * * * \\
(0.115)\end{array}$ & $\begin{array}{c}0.412 * * * \\
(0.115)\end{array}$ & $\begin{array}{c}0.414 * * * \\
(0.116)\end{array}$ & $\begin{array}{c}0.379 * * * \\
(0.116)\end{array}$ \\
\hline Owns a House & $\begin{array}{c}0.174 \\
(0.146)\end{array}$ & $\begin{array}{l}0.0904 \\
(0.148)\end{array}$ & $\begin{array}{c}0.158 \\
(0.146)\end{array}$ & $\begin{array}{l}0.0752 \\
(0.148)\end{array}$ & $\begin{array}{c}0.143 \\
(0.147)\end{array}$ \\
\hline Live with Someone & $\begin{array}{l}-0.189 \\
(0.195)\end{array}$ & $\begin{array}{l}-0.284 \\
(0.196)\end{array}$ & $\begin{array}{l}-0.231 \\
(0.196)\end{array}$ & $\begin{array}{l}-0.309 \\
(0.197)\end{array}$ & $\begin{array}{l}-0.256 \\
(0.197)\end{array}$ \\
\hline Income (midpoints) & $\begin{array}{c}0.00225^{* *} \\
(0.00108)\end{array}$ & $\begin{array}{c}0.00308 * * * \\
(0.00111)\end{array}$ & $\begin{array}{c}0.00285 * * * \\
(0.00110)\end{array}$ & $\begin{array}{c}0.00315 * * * \\
(0.00111)\end{array}$ & $\begin{array}{c}0.00295 * * * \\
(0.00110)\end{array}$ \\
\hline $\begin{array}{l}\text { Prefer not to Answer } \\
\text { Income }\end{array}$ & $\begin{array}{l}0.461 * * \\
(0.183)\end{array}$ & $\begin{array}{l}0.531 * * * \\
(0.184)\end{array}$ & $\begin{array}{l}0.517 * * * \\
(0.184)\end{array}$ & $\begin{array}{l}0.526 * * * \\
(0.184)\end{array}$ & $\begin{array}{l}0.517 * * * \\
(0.184)\end{array}$ \\
\hline Lived in Community & $\begin{array}{l}-0.0732 \\
(0.0524)\end{array}$ & $\begin{array}{l}-0.0815 \\
(0.0526)\end{array}$ & $\begin{array}{l}-0.0847 \\
(0.0525)\end{array}$ & $\begin{array}{l}-0.0808 \\
(0.0526)\end{array}$ & $\begin{array}{l}-0.0855 \\
(0.0525)\end{array}$ \\
\hline Prefer Bonds over Taxes & $\begin{array}{c}0.112 \\
(0.121)\end{array}$ & $\begin{array}{c}0.134 \\
(0.122)\end{array}$ & $\begin{array}{c}0.126 \\
(0.121)\end{array}$ & $\begin{array}{c}0.135 \\
(0.122)\end{array}$ & $\begin{array}{c}0.126 \\
(0.122)\end{array}$ \\
\hline Ideology (5-point) & $\begin{array}{c}0.0739 \\
(0.0491)\end{array}$ & $\begin{array}{c}0.0583 \\
(0.0497)\end{array}$ & $\begin{array}{c}0.0631 \\
(0.0494)\end{array}$ & $\begin{array}{c}0.0358 \\
(0.0610)\end{array}$ & $\begin{array}{c}0.0323 \\
(0.0606)\end{array}$ \\
\hline
\end{tabular}


Table 2: (Continued)

\begin{tabular}{|c|c|c|c|c|c|}
\hline Opinion & & & & & \\
\hline Climate Change Concern & & & & $\begin{array}{c}-0.0971 \\
(0.0602)\end{array}$ & $\begin{array}{l}-0.112^{*} \\
(0.0602)\end{array}$ \\
\hline Open Space Traffic & & & & $\begin{array}{c}-0.0537 \\
(0.0842)\end{array}$ & $\begin{array}{l}-0.0695 \\
(0.0842)\end{array}$ \\
\hline Government Trust (factor) & & & & $\begin{array}{c}0.192 * * * \\
(0.0608)\end{array}$ & $\begin{array}{c}0.188^{* * * *} \\
(0.0608)\end{array}$ \\
\hline Activities & & & & & \\
\hline Outdoors & & & & $\begin{array}{c}0.0339 \\
(0.0429)\end{array}$ & $\begin{array}{c}0.0406 \\
(0.0429)\end{array}$ \\
\hline Observations & 1,237 & 1,237 & 1,237 & 1,237 & 1,237 \\
\hline Neighborhood & N/A & Zip & County & Zip & County \\
\hline State FE & Yes & Yes & Yes & Yes & Yes \\
\hline Pseudo R-squared & 0.0338 & 0.0437 & 0.0394 & 0.0476 & 0.0434 \\
\hline
\end{tabular}

Notes: Regressions are ordered logit estimates with likelihood of supporting a bond measure that would preserve or create open space as the dependent variable. Standard errors are in parentheses; ${ }^{*} p<0.1, * * p<0.05, * * * p<0.01$. 
Table 3: Effect of Perception of Open Space Amount on Bond Support

(1)

(2)

(3)

(4)

(5)

Bond Bond Bond Bond Bond

VARIABLES

Support Support Support Support Support

Perception

\begin{tabular}{|c|c|c|c|c|c|}
\hline Amount & $\begin{array}{c}-0.149 * * \\
(0.0658)\end{array}$ & $\begin{array}{c}-0.153 * * \\
(0.0665)\end{array}$ & $\begin{array}{c}-0.145^{* *} \\
(0.0662)\end{array}$ & $\begin{array}{c}-0.197 * * * \\
(0.0687)\end{array}$ & $\begin{array}{c}-0.186 * * * \\
(0.0683)\end{array}$ \\
\hline \multicolumn{6}{|l|}{ Objective Measures } \\
\hline Open Space Loss & & $\begin{array}{c}0.560 \\
(0.396)\end{array}$ & $\begin{array}{c}-0.214 \\
(0.517)\end{array}$ & $\begin{array}{c}0.397 \\
(0.412)\end{array}$ & $\begin{array}{l}0.0704 \\
(0.537)\end{array}$ \\
\hline Total Open Space & & $\begin{array}{c}0.160 \\
(0.222)\end{array}$ & $\begin{array}{l}-0.376 \\
(0.342)\end{array}$ & $\begin{array}{c}0.159 \\
(0.232)\end{array}$ & $\begin{array}{l}-0.363 \\
(0.357)\end{array}$ \\
\hline \multicolumn{6}{|l|}{ Demographics } \\
\hline Age & $\begin{array}{c}0.00834 * * \\
(0.00425)\end{array}$ & $\begin{array}{l}0.00811 * \\
(0.00426)\end{array}$ & $\begin{array}{l}0.00820 * \\
(0.00426)\end{array}$ & $\begin{array}{l}0.0101 * * \\
(0.00449)\end{array}$ & $\begin{array}{l}0.0102 * * \\
(0.00448)\end{array}$ \\
\hline Female & $\begin{array}{c}0.282 * * \\
(0.118)\end{array}$ & $\begin{array}{c}0.278 * * \\
(0.119)\end{array}$ & $\begin{array}{c}0.278 * * \\
(0.119)\end{array}$ & $\begin{array}{c}0.196 \\
(0.124)\end{array}$ & $\begin{array}{c}0.199 \\
(0.124)\end{array}$ \\
\hline White & $\begin{array}{c}0.350 * * \\
(0.143)\end{array}$ & $\begin{array}{c}0.339 * * \\
(0.145)\end{array}$ & $\begin{array}{c}0.363 * * \\
(0.144)\end{array}$ & $\begin{array}{c}0.402 * * * \\
(0.150)\end{array}$ & $\begin{array}{c}0.434 * * * \\
(0.149)\end{array}$ \\
\hline College or Higher & $\begin{array}{l}0.0856 \\
(0.124)\end{array}$ & $\begin{array}{l}0.0797 \\
(0.125)\end{array}$ & $\begin{array}{l}0.0806 \\
(0.124)\end{array}$ & $\begin{array}{c}-0.0531 \\
(0.130)\end{array}$ & $\begin{array}{c}-0.0499 \\
(0.129)\end{array}$ \\
\hline Owns a House & $\begin{array}{c}-0.327 * * \\
(0.158)\end{array}$ & $\begin{array}{c}-0.349 * * \\
(0.159)\end{array}$ & $\begin{array}{c}-0.318 * * \\
(0.158)\end{array}$ & $\begin{array}{c}-0.369 * * \\
(0.167)\end{array}$ & $\begin{array}{c}-0.345 * * \\
(0.166)\end{array}$ \\
\hline Live with Someone & $\begin{array}{c}0.0810 \\
(0.215)\end{array}$ & $\begin{array}{l}0.0630 \\
(0.216)\end{array}$ & $\begin{array}{l}0.0962 \\
(0.216)\end{array}$ & $\begin{array}{l}-0.0791 \\
(0.223)\end{array}$ & $\begin{array}{l}-0.0494 \\
(0.223)\end{array}$ \\
\hline Income (midpoints) & $\begin{array}{c}0.00170 \\
(0.00123)\end{array}$ & $\begin{array}{c}0.00159 \\
(0.00124)\end{array}$ & $\begin{array}{c}0.00159 \\
(0.00124)\end{array}$ & $\begin{array}{l}0.000500 \\
(0.00125)\end{array}$ & $\begin{array}{l}0.000315 \\
(0.00124)\end{array}$ \\
\hline $\begin{array}{l}\text { Prefer not to Answer } \\
\text { Income }\end{array}$ & $\begin{array}{l}0.0146 \\
(0.194)\end{array}$ & $\begin{array}{c}-0.00153 \\
(0.195)\end{array}$ & $\begin{array}{l}0.0118 \\
(0.195)\end{array}$ & $\begin{array}{l}0.0973 \\
(0.202)\end{array}$ & $\begin{array}{l}0.0904 \\
(0.202)\end{array}$ \\
\hline Lived in Community & $\begin{array}{l}-0.0103 \\
(0.0555)\end{array}$ & $\begin{array}{l}-0.00488 \\
(0.0557)\end{array}$ & $\begin{array}{l}-0.00897 \\
(0.0557)\end{array}$ & $\begin{array}{c}0.0120 \\
(0.0576)\end{array}$ & $\begin{array}{c}0.0122 \\
(0.0577)\end{array}$ \\
\hline Prefer Bonds over Taxes & $\begin{array}{c}-0.292 * * \\
(0.133)\end{array}$ & $\begin{array}{c}-0.300 * * \\
(0.133)\end{array}$ & $\begin{array}{c}-0.290 * * \\
(0.133)\end{array}$ & $\begin{array}{l}-0.189 \\
(0.140)\end{array}$ & $\begin{array}{l}-0.183 \\
(0.140)\end{array}$ \\
\hline Ideology (5-point) & $\begin{array}{c}-0.651 * * * \\
(0.0571)\end{array}$ & $\begin{array}{c}-0.658 * * * \\
(0.0573)\end{array}$ & $\begin{array}{l}-0.648 * * * \\
(0.0572)\end{array}$ & $\begin{array}{c}-0.243 * * * \\
(0.0679)\end{array}$ & $\begin{array}{c}-0.233 * * * \\
(0.0678)\end{array}$ \\
\hline
\end{tabular}


Table 3: (Continued)

\begin{tabular}{|c|c|c|c|c|c|}
\hline Opinion & & & & & \\
\hline Climate Change Concern & & & & $\begin{array}{c}0.737 * * * \\
(0.0685)\end{array}$ & $\begin{array}{c}0.739 * * * \\
(0.0687)\end{array}$ \\
\hline Open Space Traffic & & & & $\begin{array}{c}-0.389 * * * \\
(0.0924)\end{array}$ & $\begin{array}{c}-0.387 * * * \\
(0.0925)\end{array}$ \\
\hline Government Trust (factor) & & & & $\begin{array}{c}0.0834 \\
(0.0665)\end{array}$ & $\begin{array}{c}0.0795 \\
(0.0665)\end{array}$ \\
\hline \multicolumn{6}{|l|}{ Activities } \\
\hline Outdoors & & & & $\begin{array}{c}0.231 * * * \\
(0.0511)\end{array}$ & $\begin{array}{c}0.238 * * * \\
(0.0512)\end{array}$ \\
\hline Observations & 1,237 & 1,237 & 1,237 & 1,237 & 1,237 \\
\hline Neighborhood & N/A & Zip & County & Zip & County \\
\hline State FE & Yes & Yes & Yes & Yes & Yes \\
\hline Pseudo R-squared & 0.102 & 0.103 & 0.102 & 0.173 & 0.173 \\
\hline
\end{tabular}

Notes: Regressions are ordered logit estimates with likelihood of supporting a bond measure that would preserve or create open space as the dependent variable. Standard errors are in parentheses; $* p<0.1, * * p<0.05$, *** $p<0.01$. 